\title{
Pelatihan Penulisan Artikel Ilmiah Penelitian Tindakan Kelas untuk Publikasi pada Jurnal Ilmiah
}

\author{
Patrisius Afrisno Udil \\ Pendidikan Matematika, FKIP Universitas Nusa Cendana \\ Email: afrisno.udil@staf.undana.ac.id
}

\begin{abstract}
One of the classical issues teachers face in East Nusa Tenggara is the lack of academic articles based on scientific research, including Classroom Action Research (CAR). It was happened because of the low interest, motivation, and ability of teachers to write the research in the form of an academic article and publish it in an academic journal. Therefore, it was essential to hold training on writing CAR articles for publication in academic journals. It aims to improve the ability of teachers to write CAR article and publish it in academic journals. This activity is running in the form of online training. The methods used in implementing activities include webinars through zoom meetings, presentations, discussion, training, and mentoring through WhatsApp Group. This activity hold in two stages, namely the preparation stage and the implementation stage. The result of the activity indicates the high enthusiasm of participants both during the webinar and training and mentoring. In addition, this activity can also improve the participants' understanding and abilities in making or writing good CAR article for publication in academic journals.
\end{abstract}

Keywords: classroom action research, CAR article, scientific article, journal

\section{Untuk Sitasi :}

Udil, P. A. (2021). Pelatihan penulisan artikel ilmiah penelitian tindakan kelas untuk publikasi pada jurnal ilmiah. Jurnal Nasional Pengabdian Masyarakat, 2(1). 21-27.

\section{Pendahuluan}

Dalam Undang-Undang Nomor 14 Tahun 2005 tentang Guru dan Dosen, secara eksplisit dinyatakan bahwa guru merupakan pendidik profesional dengan tugas utama mendidik, mengajar, membimbing, mengarahkan, melatih, menilai, dan mengevaluasi peserta didik. Tugas guru untuk menilai dan mengevaluasi peserta didik tidak hanya terbatas pada proses memberikan nilai bagi peserta didik atas proses dan hasil belajaranya. Lebih dari itu, penilaian dan evaluasi guru juga terkait dengan serangkaian upaya guru untuk menganalisis proses dan hasil belajar, mengidentifikasi berbagai masalah, dan merencanakan alternatif solusi untuk perbaikan lebih lanjut. Guru dapat menganalisis proses dan hasil belajar, mengidentifikasi berbagai masalah, dan merencanakan alternatif solusi untuk perbaikan lebih lanjut dengan melakukan penelitian terkait proses dan hasil belajar yang dijalankannya. Dengan kata lain, guru perlu melakukan penelitian sebagai bagian tidak terpisahkan dari tugasnya untuk menilai dan mengevaluasi peserta didik.

Salah satu jenis penelitian yang dapat dilakukan oleh guru adalah Penelitian Tindakan Kelas (PTK). Penelitian tindakan kelas merupakan bentuk usaha evaluasi pembelajaran yang dilakukan di dalam kelas (Dewi, dkk., 2017). Syah (2016) menyebutkan bahwa penelitian 
tindakan kelas memungkinkan guru untuk mengeksplorasi dan menyelidiki berbagai tantangan, masalah, dan ide yang ingin dipahami secara mendalam pada kelasnya. Di samping itu, Herlina, dkk. (2018) juga menyatakan bahwa "the action research process provides opportunity for teachers to self-assess their practice and make timely instructional decisions based on student outcomes, as teacher-educators". Sementara Stringer (2007) mendefinisikan penelitian tindakan (action research) sebagai pendekatan sistematik yang dimaksudkan untuk menemukan solusi yang efektif atas masalah yang dihadapi. Dengan demikian, penelitian tindakan kelas dalam hal ini dapat dipandang sebagai usaha sistematik yang dilakukan guru untuk menganalisis berbagai tantangan dan masalah dalam pembelajaran serta menemukan alternatif solusi yang efektif atas masalah tersebut sehingga dapat meningkatkan kualitas pembelajaran.

Selain melakukan penelitian, guru juga perlu menulis dan mempubikasikan hasil penelitian tersebut dalam bentuk artikel ilmiah. Publikasi hasil penelitian dimaksudkan agar berbagai masalah yang ditemukan dan inovasi yang dihasilkan dalam penelitian tersebut dapat menjadi referensi bagi guru-guru di tempat lain. Dalam hal ini, salah satu cara yang efektif untuk mempresentasikan hasil penelitian adalah dengan menulis dan mempublikasikannya dalam bentuk artikel ilmiah pada jurnal ilmiah (Arta, 2018). Lebih lanjut, publikasi artikel ilmiah hasil penelitian pada jurnal ilmiah merupakan salah satu bentuk profesionalisme guru dan upaya meningkatkan kualitas pembelajaran (Dewi, dkk., 2017). Senada dengan hal tersebut, Syahmani, dkk. (2020) menyebutkan bahwa guru perlu menuangkan dan mempublikasikan hasil penelitian tindakan kelas dalam bentuk artikel ilmiah sebagai bentuk penyebarluasan ilmu pengetahuan sekaligus evaluasi kompetensi diri sebagai pengajar.

Namun demikian, semangat dan antusiasme guru untuk melakukan penelitian, menulis artikel ilmiah, dan mempublikasikannya pada jurnal ilmiah masih menjadi salah satu tantangan yang perlu dibenahi. Widagdo dan Susilo (2018) menegaskan bahwa kemauan dan kemampuan guru dalam menulis artikel ilmiah masih perlu ditingkatkan. Lebih lanjut, disampaikan fakta terkait banyaknya guru yang belum mampu menghasilkan karya ilmiah yang baik. Pelaksanaan penelitian tindakan kelas dan penulisan artikel ilmiah masih menjadi beban dan tantangan yang berat bagi sebagian besar guru (Dewi, dkk., 2017). Beberapa alasan terkait masalah tersebut disampaikan Arta (2018) antara lain: (1) kurangnya pengetahuan, pemahaman, dan keterampilan guru dalam menulis karya ilmiah, khususnya menulis artikel ilmiah, (2) terbatasnya sarana bacaan ilmiah terutama yang berupa majalah ilmiah atau jurnal, (3) belum tersedianya majalah atau jurnal di lingkungan sekolah atau dinas pendidikan kabupaten yang bisa menampung tulisan para guru, (4) masih terbatasnya penyelenggaraan lomba menulis karya ilmiah yang diselenggarakan oleh dinas pendidikan baik pada tingkat nasional, tingkat provinsi maupun pada tingkat kabupaten, dan (5) masih rendahnya motivasi guru untuk mengikuti lomba menulis karya ilmiah.

Dengan demikian, dapat dikatakan bahwa masih begitu banyak masalah dan tantangan yang perlu dibenahi untuk mendorong dan meningkatkan minat, motivasi, dan kemampuan guru untuk menulis artikel ilmiah PTK dan mempublikasikannya pada jurnal ilmiah. Sehubungan dengan itu, pelatihan penulisan artikel ilmiah penelitian tindakan kelas untuk publikasi pada jurnal dapat menjadi salah satu strategi yang bisa dilakukan.

\section{Metode Pelaksanaan}

Kegiatan pengabdian masyarakat ini dilakukan dalam bentuk pelatihan online. Metode yang digunakan dalam pelaksanaan kegiatan ini antara lain webinar (presentasi materi, tanya jawab, 
dan diskusi secara daring melalui zoom meeting), pelatihan dan pendampingan secara daring dengan WhattsApp Group. Adapun peserta dalam kegiatan webinar sebanyak 300 orang yang meliputi guru dan calon guru dari berbagai sekolah dan daerah di Nusa Tenggara Timur, sedangkan peserta yang kemudian terlibat dalam sesi pelatihan dan pendampingan berjumlah 50 orang. Kegiatan ini dilaksanakan melalui beberapa tahapan yang diuraikan sebagai berikut.

\subsection{Tahap persiapan}

Pada tahap persiapan beberapa aktivitas yang dilakukan antara lain analisis isu dan permasalahan, koordinasi dan penetapan waktu pelaksanaan kegiatan, sosialisasi pelaksanaan kegiatan melalui flyer dan media sosial, menyiapkan berbagai sarana pendukung untuk pelaksanaan kegiatan, menyiapkan materi webinar dan pelatihan penulisan artikel ilmiah PTK untuk publikasi pada jurnal ilmiah.

\subsection{Tahap pelaksanaan}

Pelaksanaan kegiatan meliputi pelaksanaan webinar dalam bentuk pemaparan materi dan diskusi secara daring melalui zoom meeting dan live streaming youtube. Adapun materi yang disajikan dan didiskusikan antara lain terkait konsep PTK, sistematika PTK, strategi merancang dan menulis artikel ilmiah, dan prosedur menulis dan mempublikasikan artikel ilmiah PTK pada jurnal ilmiah. Setelah itu, diberikan pelatihan dan pendampingan penulisan artikel ilmiah PTK bagi peserta kegiatan. Pelatihan dan pendampingan dilakukan melaui WhatsApp Group dengan tahapan sebagai berikut: (1) studi kasus beberapa artikel PTK, (2) penyusunan artikel PTK secara mandiri oleh peserta, dan (3) diskusi dan pendampingan lebih lanjut terkait artikel yang telah dibuat peserta sehingga menghasilkan draft artikel ilmiah yang layak untuk dipublikasikan pada jurnal ilmiah.

\section{Hasil Pelaksanaan dan Diskusi}

Kegiatan pengabdian masyarakat ini dilaksanakan dalam bentuk pelatihan dan mencakup beberapa tahapan dan aktivitas seperti dipaparkan berikut ini.

\subsection{Tahap persiapan}

Tahap persiapan dilakukan sejak bulan April sampai Mei 2020. Pada tahap persiapan beberapa aktivitas yang dilakukan antara lain analisis isu dan permasalahan, koordinasi dan penetapan waktu pelaksanaan kegiatan, menyiapkan berbagai sarana pendukung untuk pelaksanaan kegiatan, menyiapkan materi webinar dan pelatihan penulisan artikel ilmiah PTK untuk publikasi pada jurnal ilmiah.

1) Analisis isu dan permasalahan dilakukan dengan berdiskusi bersama tim dosen pengabdian masyarakat serta menelaaah berbagai literatur ilmiah untuk mengidentifikasi berbagai potensi isu dan masalah terutama terkait pembelajaran matematika selama masa pandemic Covid-19. Hasil analisis isu dan masalah menunjukkan rendahnya minat, motivasi, dan kemampuan guru untuk menulis artikel ilmiah PTK dan mempublikasikannya pada jurnal ilmiah. Hal ini mendorong dan melatarbelakangi dilakukannya pelatihan penulisan artikel ilmiah PTK untuk publikasi pada jurnal ilmiah.

2) Pada tahap ini, juga ditetapkan waktu pelaksanaan webinar yaitu tanggal 06 Mei 2021. Setelah waktu pelaksanaan kegiatan disepakati, dilakukan sosialisasi terkait kegiatan yang dimaksud. Adapun sosialisasi yang dimaksud dilakukan dengan membuat flyer yang disebarluaskan melalui media sosial.

3) Persiapan lain yang dilakukan antara lain menyiapkan sarana pendukung kegiatan antara 
lain zoom meeting, sertifikat, form registrasi dan absensi dalam bentuk google form, dan berbagai hal teknis lain terkait pelaksanaan webinar.

4) Pada tahap persiapan juga dilakukan penyusunan materi webinar dan pelatihan.

\subsection{Tahap pelaksanaan}

\subsubsection{Pelaksanaan webinar}

Kegiatan webinar dilakukan pada tanggal 06 Mei 2021. Webinar dilaksanakan dalam bentuk pemaparan materi dan diskusi secara daring melalui zoom meeting dan live streaming youtube. Webinar ini dimakusdkan untuk membekali peserta dengan berbagai konsep dasar terkait PTK dan artikel ilmiah sebelum mulai merancang dan membuat artikel ilmiah PTK. Melalui pemaparan materi dan diskusi selama webinar, peserta diharapkan dapat memahami secara teoritis bagaiamana membuat artikel ilmiah PTK yang baik dan layak untuk dipublikasikan pada jurnal ilmiah. Pemaparan materi dimulai dengan penjelasan konsep dasar, tahapan, dan sistematika PTK bagi peserta. Meskipun sebagian besar peserta sejatinya telah mengenal dan mengetahui PTK, pemaparan materi konsep dasar, tahapan, dan sistematika PTK tetap perlu diberikan sebagai upaya mengingatkan kembali apa yang telah diketahui peserta dan meluruskan beberapa kekeliriuan yang dialami peserta.
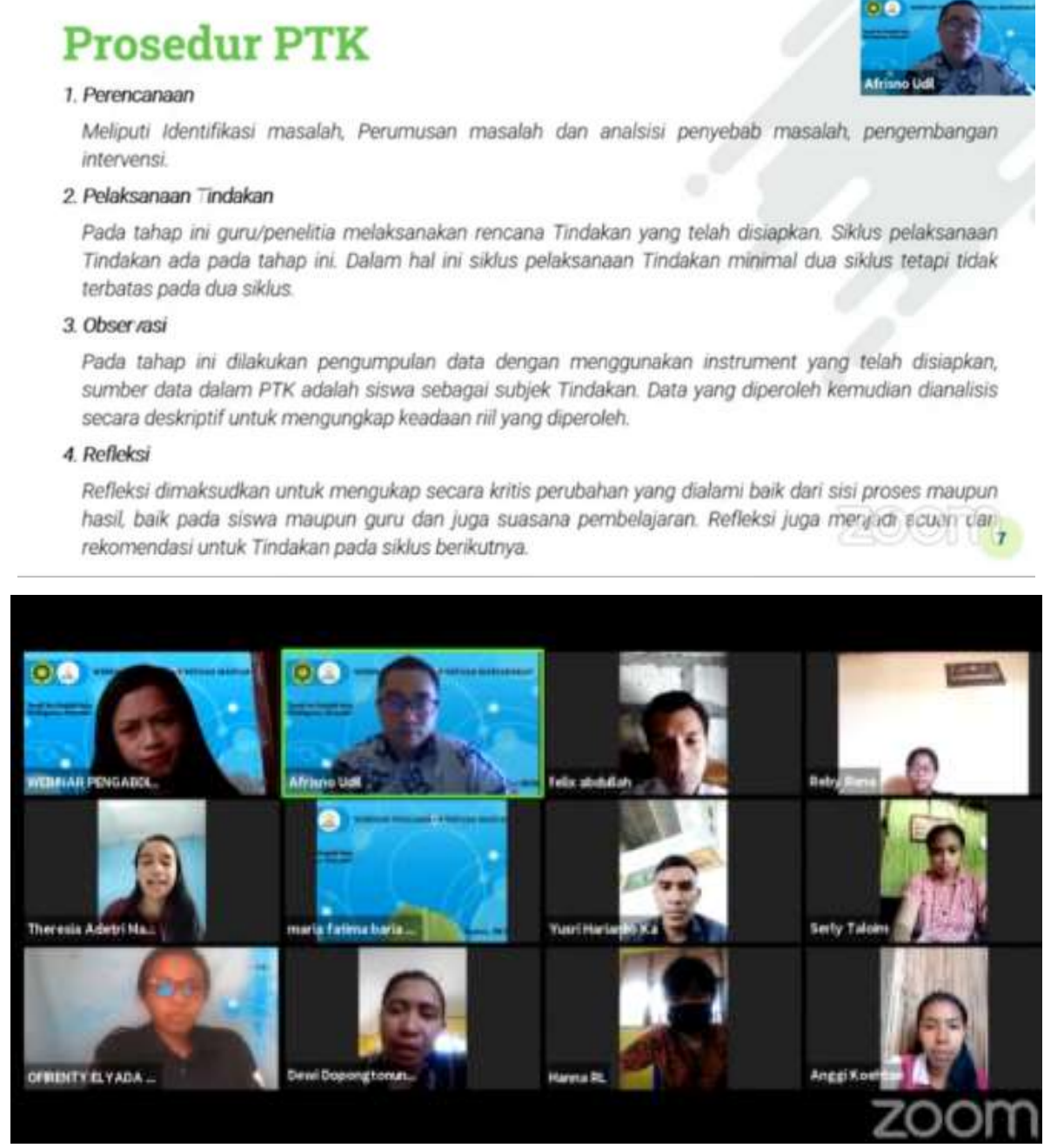

Gambar 1. Pemaparan materi dan diskusi saat webinar 
Selanjutnya dijelaskan materi terkait strategi merancang dan menulis artikel ilmiah, serta prosedur menulis dan mempublikasikan artikel ilmiah PTK pada jurnal ilmiah. Materi ini dipandang perlu untuk memberikan gambaran bagi peserta bagaimana menuangkan hasil penelitian PTK yang diperoleh menjadi suatu artikel ilmiah yang layak untuk dipublikasikan pada jurnal ilmiah. Setelah pemaparan materi tersebut dilanjutkan dengan diskusi dan tanya jawab. Secara umum peserta antusias dengan pemaparan materi dan diskusi yang dilakukan. Salah satu hal yang menjadi komentar peserta terkait materi ini adalah perlunya dilakukan webinar dan pendampingan secara berkala dan berkelanjutan sehingga peserta bisa menjaga serta meningkatkan kualitas dan produktivitas untuk menghasilkan artikel ilmiah yang layak untuk dipublikasikan.

\subsubsection{Pelaksanaan pelatihan dan pendampingan}

Pelatihan dan pendampingan penulisan artikel ilmiah PTK diikuti oleh 50 peserta yang telah memperoleh materi pada sesi webinar. Pelatihan dan pendampingan ini dilaksanakan sejak tanggal 07 Mei 2021 sampai 13 Mei 2021. Adapun pelatihan dan pendampingan dilakukan melaui WhatsApp Group dengan tahapan sebagai berikut.

\section{Analisis dan Studi Kasus Artikel PTK}

Aktivitas pertama yang dilakukan pada sesi pelatihan dan pendampingan adalah analisis atau studi kasus artikel PTK yang telah disiapkan dengan judul "Penerapan Model Problem Based Learning untuk Meningkatkan Hasil Belajar Matematika pada Materi Segitiga Siswa Kelas VII SMPN XX Kota Kupang Tahun Ajaran 2020/2021”. Pada aktivitas ini peserta diminta untuk memberikan komentar terkait kekurangan dan kelebihan dari artikel PTK tersebut.

Sebanyak 9 peserta (18\%) menyatakan bahwa artikel yang ditelaah dapat dikategorikan baik karena telah memenuhi kaidah keilmiahan artikel baik dari segi metode, substansi, maupun sistematika dan teknis penulisan. Sementara 27 peserta (54\%) berpendapat bahwa artikel yang ditelaah masih terdapat kekurangan yang perlu diperbaiki terutama yang terkait dengan sistematika dan teknis penulisan seperti kesalahan penulisan/pengetikan, tanda baca, tata bahasa. Adapun 14 peserta (28\%) yang lain, selain mampu mengidentifikasi kekurangan artikel terkait aspek penulisan yang telah disebutkan di atas, juga menemukan berbagai kekurangan seperti teknik sitasi dan penulisan rujukan yang belum tepat, judul yang terlalu panjang, maupun kekurangan aspek substansi seperti argumentasi masalah yang kurang kuat serta tujuan penelitian yang menggambarkan urgensi penelitian masih belum tampak.

Hasil analisis dan studi kasus artikel PTK ini menunjukkan bahwa masih terdapat peserta yang belum mampu mengidentifikasi secara baik dan lengkap kekurangan pada artikel PTK yang diberikan, meskipun ada juga peserta yang telah mampu menganalisis dengan baik kekurangan artikel yang diberikan. Hal ini pun sejalan dengan temuan Dewi, dkk (2017) yang menemukan fakta serupa bahwa sebagian guru telah mampu mengidentifikasi setiap komponen isi dalam artikel ilmiah berbasis PTK dengan sangat rinci.

\section{Penyusunan artikel PTK dan pendampingan}

Setelah melakukan analisis dan studi kasus artikel PTK, selanjutnya peserta dilatih untuk menyusun artikel PTK berdasarkan hasil penelitian PTK yang telah dilakukan masing-masing sebelumnya. Adapun peserta yang mengumpulkan artikel sampai waktu yang ditentukan yaitu tanggal 13 Mei 2021 sebanyak 34 orang. Pada sesi ini, peserta pertama-tama diminta untuk merumuskan judul artikel ilmiah, melengkapi bagian nama penulis, instansi penulis, email penulis, abstrak, dan kata kunci. Selanjutnya peserta diminta untuk menyusun bagian isi 
artikel mulai dari pendahuluan, metode, hasil dan pembahasan, simpulan dan saran. Kemudian, peserta diminta untuk melengkapi daftar pustaka.

Adapun hasil pendampingan sampai hari terakhir menunjukkan bahwa semua peserta telah mampu merumuskan judul yang baik yaitu terdiri dari maksimal 15 kata, bersifat informatif, dan mewakili variabel (masalah dan treatment) dalam penelitian (Dewi, dkk., 2017). Hal yang sama pun ditemukan pada bagian institusi, email, dan kata kunci, semua peserta mampu menuliskan dengan baik sesuai kriteria. Sementara pada bagian nama penulis masih terdapat beberapa peserta yang menyertakan gelar pada bagian nama penulis. Pada bagian abstrak secara umum telah memuat masalah, tujuan, prosedur, dan hasil penelitian. Namun masih terdapat beberapa peserta yang menyertakan beberapa teori terkait variabel sehingga menyebabkan abstrak menjadi panjang. Pada bagian pendahuluan, masih terdapat peserta yang belum mampu menyusun pendahuluan yang baik dan lengkap. Berbagai kekurangan yang ditemukan misalnya belum menjelaskan secara baik masalah penelitan dan kaitan antara treatment dengan masalah. Pada bagian metode secara umum semua peserta telah menuliskan dengan baik mulai dari kelengkapan tahapan dan prosedur PTK sampai pada instrumen penelitian dan teknik analisis data. Pada bagian hasil dan pembahasan masih terdapat peserta yang belum mampu menguraikan hasil dan pembahasan dengan baik. Secara khusus masih terdapat peserta yang hanya mendeskripsikan hasil penelitian dengan kata-kata tanpa menghubungkannya dengan pertanyaan atau masalah yang diteliti. Pada bagian simpulan dan saran, sebagaian besar peserta telah mampu mampu merumuskan simpulan dan saran yang baik. Pada bagian daftar pustaka, secara umum peserta telah mampu menuliskan rujukan dengan lengkap, meskipun masih terdapat penulisan yang tidak konsisten. Berdasarkan hasil pendampingan yang dilakukan, dapat dikatakan bahwa peserta secara umum telah memahami dan mampu menyusun artikel ilmiah PTK yang baik, meskipun terdapat beberapa peserta yang perlu mendapatkan pendampingan lanjutan.

\section{Kesimpulan}

Berdasarkan hasil dan pembahasan di atas dapat disimpulkan beberapa hal berikut.

1) Kegiatan pelatihan penulisan artikel ilmiah PTK untuk publikasi pada jurnal ilmiah dapat meningkatkan pemahaman dan kemampuan, serta keterampilan peserta dalam membuat artikel ilmiah PTK yang layak untuk dipublikasikan pada jurnal ilmiah.

2) Selain itu, disimpulkan juga bahwa masih terdapat beberapa peserta yang perlu mendapatkan pelatihan dan pendampingan lanjutan untuk meningkatkan kemampuan dan keterampilan menulis artikel ilmiah PTK yang layak dipublikasikan pada jurnal ilmiah.

\section{Saran}

Berdasarkan hasil pelaksanaan dan simpulan kegiatan ini disampaikan saran dari hasil kegiatan ini adalah perlunya dilakukan pelatihan serupa secara berkala dan berkelanjutan.

\section{Daftar Pustaka}

Arta, K. S. (2018). Pelatihan penulisan artikel untuk publikasi di jurnal ilmiah untuk meningkatkan profesionalisme bagi guru-guru di Kecamatan Kubutambahan Kabupaten Buleleng, Prosiding Seminar Nasional Hukum dan Ilmu Sosial Ke-2, 146-159. Universitas Pendidikan Ganesha.

Dewi, P. K., Rizal, M. S., Ardhian, D., Hardinata, V., \& Lestari, Y. D. (2017). Pelatihan 
penulisan artikel ilmiah berbasis penelitian tindakan kelas pada guru SMP, Jurnal Abdi, 2(2), $7-17$.

Herlina, R., Kurnia, A. D., Faridah, D. (2018). Teachers' perception on classroom action research in english education among english teachers in Ciamis West Java, Journal of Applied Linguistics and Literacy, 2 (1), 45-49.

Stringer, E.T. (2007). Action Research. Third Ed. California: Sage Publications Inc.

Syah, M. N. S. (2016). Classroom action research as professional development of teachers in Indonesia. Jurnal Tarbawi, 13 (1), 1-15.

Syahmani, Rusmansyah, Winarti, A., Almubarak. (2020). Penulisan artikel ilmiah berbasis penelitian tindakan kelas (PTK) untuk meningkatkan kualitas pengajaran dan pembelajaran di SMA Banjarmasin Kalimantan Selatan, Jurnal Terapan Abdimas, 5(2), 163-172.

Undang-Undang Republik Indonesia Nomor 14 Tahun 2005 Tentang Guru dan Dosen.

Widagdo, A., \& Susilo. (2018). Pelatihan penulisan artikel ilmiah bagi guru-guru SD di Kecamatan Kendal, Abdimas Unwahas, 3 (3), 25-29. 